\title{
A new species of Rhizopogon from Kashmir valley, India
}

\author{
Mehrajud Din Talie, Abdul Hamid Wani, Wasim Sajad Malik, Mohd Yaqub Bhat* \\ Department of Botany, Section of Mycology and Plant Pathology, University of Kashmir, Srinagar (190006), India. \\ *Corresponding authorEmail: myaqub35@gmail.com \\ (Submitted on September 21,2020; Accepted on December 7, 2020)
}

\begin{abstract}
A new species of Rhizopogon Fr. \& Nordholm, R. cashmerianus associated with Pinus wallichiana was collected and identified for the first time from Kashmir Himalaya. It was characterized and identified on morpho-anatomical and molecular basis by analysis of ITS sequences. The fungal molecular marker (ITS-rDNA) was amplified using universal fungal primers (ITS1F and ITS4R). Bioinformatic data retrieved for its molecular identification and the rDNA sequence, when aligned in GenBank by performing BLAST indicates that $R$. cashmerianus is a new species. The rDNA sequence of this species forms a distinct clade from the rest of species of the same genus. Therefore, this species is being described for the first time from Kashmir Valley.
\end{abstract}

KEYWORDS: Molecular identification, morpho-anatomical characterization, phylogenetic analysis, Rhizopogon .

\section{INTRODUCTION}

The genus, Rhizopogon Fr. \& Nordholm belonging to Division: Basidiomycota, order: Boletales, and family: Rhizopogonaceae which contains approximately 150 species of hypogeous or subepigeous ectomycorrhizal fungi (Kirk et al., 2008). They are reported to form ectomycorrhizal association with members of family Pinaceae and are found growing throughout the world in natural habitats (Molina et al., 1999). The epigeous mushroom genera such as Suillus, Gomphidius and Chroogomphus are thought to be possible ancestors of Rhizopogon. However, it is believed to be evolved from Suillus like ancestor because of its reduced morphological and other characteristics (Bruns et al., 1989). It is considered a difficult genus but Smith and Zeller (1966) provided good account of the species of Rhizopogon and Grubisha et al. (2002) re-examined the infrageneric relationships based on phylogenetic analysis of ITS sequences. Phylogenetic analysis of ITS sequences also revealed that ectomycorrhizal associates of key conifer genera such as Pinus and Abies were scattered across numerous subgenera of Rhizopogon (Smith and Zeller, 1966; Grubisha et al.,2002). Till now, about 280 species of mushrooms have been reported from Kashmir Valley (Dar et al., 2009, 2010; Pala et al., 2011, 2012; Wani et al., 2010, 2015; Malik et al., 2018). The mushroom diversity of Kashmir Himalaya is still at its infancy and needs further exploration as major portion has remained unexplored. The present study was carried out to explore the mushroom diversity of Kashmir Valley. To date some species of Rhizopogon have been reported from the Kashmir Himalaya, viz. R. vulgaris (Vittad) M. Lange (1956), Rhizopogon villosulus Zeller (1941), Rhizopogon roseolus (Corda) Th. Fr. (1909) and Rhizopogon sp. (Beig et al., 2011; Malik et al., 2017). During the present mushroom survey, a new species of Rhizopogon associated with Pinus wallichiana was identified and is being described here.

\section{MATERIALS AND METHODS}

Sampling of mushrooms: The various sites explored during the present study were Lolab, Handwara, Wadpora and BungusValley of Kupwara District in J\&K UT (Fig.1).

The method given by (Halling, 1996) was followed for the field trips. Standard methods were followed for the collection of sporocarps as given by (Atri et al., 2005). Sporocarps were carefully dugout with the help of a knife and photographed in the field using Sony SLR Digital field camera and Sony cyber shot 12.1 megapixel Camera. Field characteristics such as distribution, shape, size and colour were recorded from fresh specimens. Wet preservation was carried out in FAA (Formaldehyde acetic acid) solution for Herbarium purpose. The specimen with the voucher specimen No. KASH-2922 have been deposited, in the Mycological Section of KASH Herbarium, Centre of Plant Taxonomy, Division of Botany, University of Kashmir, Srinagar, Jammu and Kashmir, India (190006).

Morpho-anatomical examination: Macroscopic characteristics such as colour, shape and size of basidiocarp; colour of gleba; colour and texture of periderm; presence or absence of columella and nature of rhizomorphs were described from fresh specimens. Hand cut sections of mushroom specimen was mounted in water, Congo red, Melzer's reagent, and 3\% $\mathrm{KOH}$ and examined under Trinocular Microscope at the University Scientific Instrumentation Centre for morphological identification (Castellano et al., 2012). The identification was carried out by consulting authentic literature (Smith and Zeller, 1966; Arora, 1986; Castellano et al., 1989; Trappe et al., 2009; Mujic et al., 2019).

DNA extraction and Agarose Gel electrophoresis: The total genomic DNA was extracted from dried fruiting body tissue using NucleoSpin ${ }^{\circledR}$ Plant II Kit (Macherey-Nagel). The quality of isolated DNA was analyzed by agarose gel electrophoresis. $1 \mu \mathrm{L}$ of $6 \mathrm{X}$ gel-loading buffer was added to $5 \mu \mathrm{L}$ of isolated DNA. The samples were loaded to $0.8 \%$ agarose gel prepared in $0.5 \mathrm{X}$ TBE (Tris-Borate-EDTA) buffer containing $0.5 \mu \mathrm{g} / \mathrm{mL}$ ET Br. Electrophoresis was performed at $0.5 \mathrm{X}$ TBE as electrophoresis buffer at $75 \mathrm{~V}$ until the migration of bromophenol dye to the bottom of the gel was observed. The UV transilluminator was used to visualize the gels and Gel documentation system was used to capture images.

PCR amplification: PCR reactions were carried in a $20 \mu \mathrm{L}$ reaction mixture containing $1 \mathrm{X}$ Phire PCR buffer 


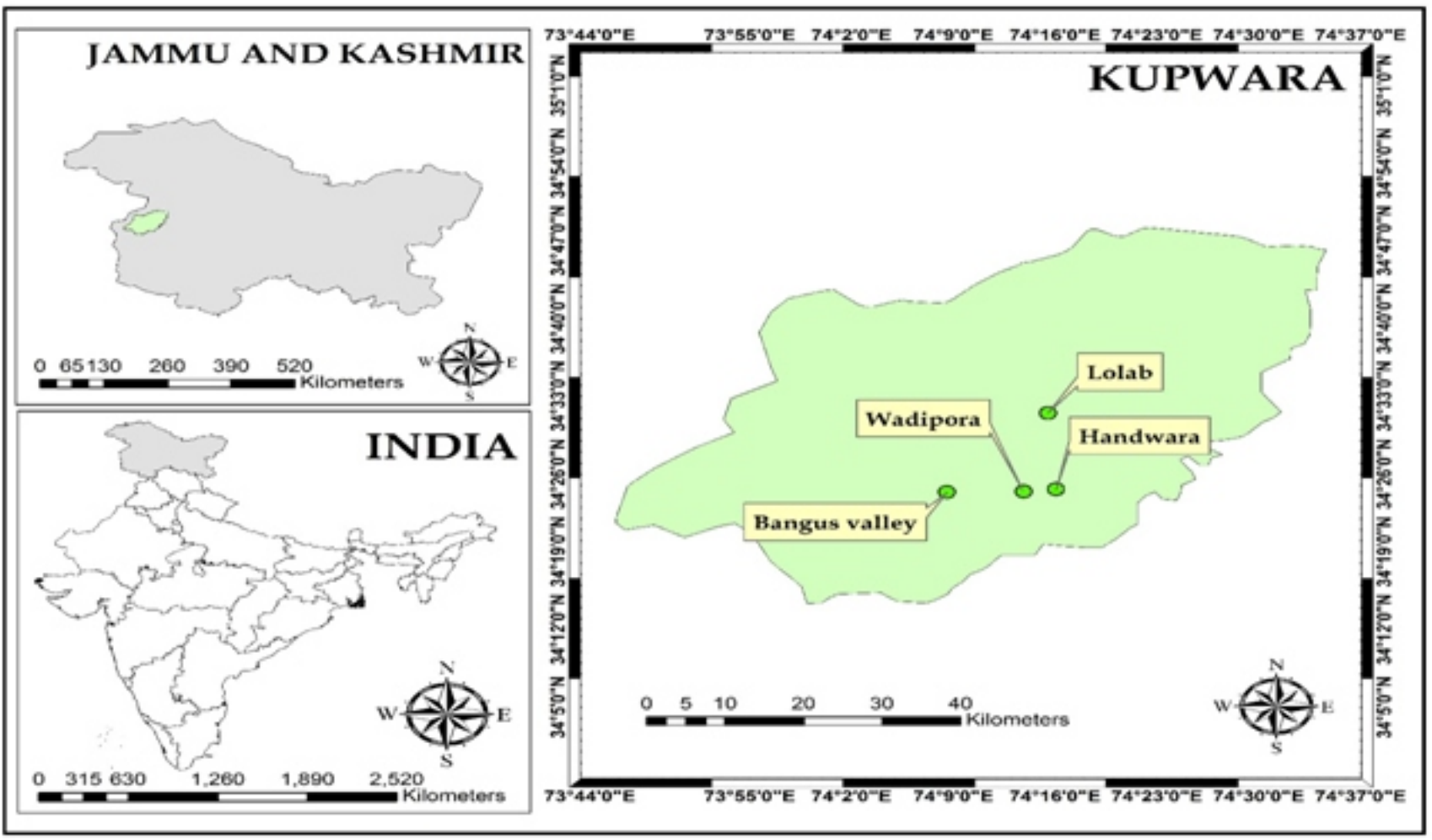

Fig. 1. Map showing the surveyed area of Kupwara District of Jammu and Kashmir, India.

(comprising $1.5 \mathrm{mM} \mathrm{MgCl}$ ), $0.2 \mathrm{mM}$ each dNTPs (dATP, dGTP, dCTP and dTTP), $1 \mu$ LDNA, $0.2 \mu \mathrm{L}$ Phire Hotstart II DNA polymerase enzyme, $0.1 \mathrm{mg} / \mathrm{mL}$ BSA and $3 \% \mathrm{DMSO}, 0.5 \mathrm{M}$ Betaine, $5 \mathrm{pM}$ of forward and reverse primers using PCR thermal cycler (GeneAmp PCR System 9700, Applied Biosystems) (White et al., 1990).

PCR amplification profile

\begin{tabular}{rlr}
$98{ }^{\circ} \mathrm{C}-$ & $30 \mathrm{sec}$ \\
$98{ }^{\circ} \mathrm{C}-$ & $5 \mathrm{sec}$ \\
$58{ }^{\circ} \mathrm{C}-$ & $10 \mathrm{sec}$ \\
$72{ }^{\circ} \mathrm{C}-$ & $15 \mathrm{sec}$ \\
$72{ }^{\circ} \mathrm{C}-$ & $60 \mathrm{sec}$ \\
${ }^{\circ} \mathrm{C}-$ & \multicolumn{1}{c}{$-\infty$}
\end{tabular}

To $5 \mu \mathrm{L}$ of PCR product, $1 \mu \mathrm{L}$ of $6 \mathrm{X}$ loading dye was added and loaded to $1.2 \%$ agarose gel which was made in $0.5 \mathrm{X}$ TBE buffer comprising $0.5 \mu \mathrm{g} / \mathrm{mL}$ ET Br. Electrophoresis was performed at $75 \mathrm{~V}$ for 1-2 hours till the migration of bromophenol dye to the bottom of the gel was observed. The UV transilluminator was used to visualize the gels and Gel documentation system was used to capture images (Fig.2).

Sequencing: The PCR thermal cycler (GeneAmp PCR System 9700, Applied Biosystems) was used to perform the sequencing reaction using BigDye Terminator v3.1Cycle sequencing Kit concomitant to manufactures protocol. The sequence quality was assessed using Sequence Scanner Software v1 (Applied Biosystems). The isolated ITS sequence was with an ORF of 405 bps. The sequence was submitted to National Center for Biotechnology Information

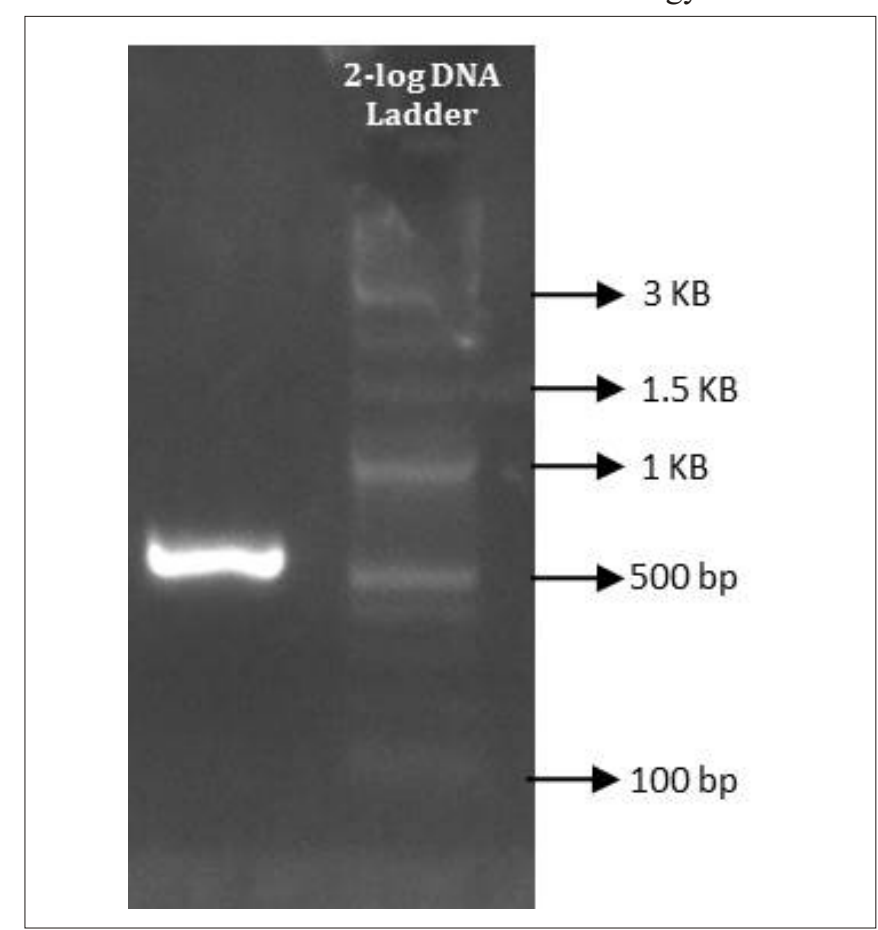

Fig. 2 1. $2 \%$ Agarose gel showing amplified ITS rDNA PCR Product against the molecular standard of 2-log DNA ladder ranging from $100 \mathrm{bp}$ to $3 \mathrm{~kb}$. 
(NCBI) data base with accession submission R_KMK692540.

Phylogenetic analysis: The nucleic acid sequences were aligned using Clustal Omega Multiple Sequence Alignment tool and the phylogenetic analysis was performed using the Clustal W program and MEGA 7 software (Jukes and Cantor, 1969; Kumar et al., 2016).

About 20 nucleic acid sequences were selected from different species submitted to NCBI database(Table-1).

Table-1: Database of materials used for molecular analyses

\begin{tabular}{lll}
\hline Species Name & $\begin{array}{l}\text { GeneBank } \\
\text { Number of ITS }\end{array}$ & References \\
\hline Rhizopogon sp. & MH878753.1 & From Genebank \\
Rhizopogon sp. & MH878765.1 & From Genebank \\
Rhizopogon guzmanii & KC152201.1 & From Gene bank \\
Rhizopogon milleri & MH819344.1 & From Gene bank \\
Rhizopogon subpurpurascens & MH298904.1 & From Gene bank \\
Rhizopogon atroviolaceus & KT968584.1 & From Gene bank \\
Rhizopogon chamaleontinus & KP859270.1 & From Gene bank \\
Rhizopogon semitectus & KP859275.1 & From Gene bank \\
Rhizopogon subbadius & NR_121274.1 & From Gene bank \\
Rhizopogon salebrosus & HQ914337.1 & From Gene bank \\
Rhizopogon sp. Siskiyou & AF377172.1 & From Gene bank \\
Rhizopogon milleri & NR_119445.1 & From Gene bank \\
Rhizopogon kauffmanii & NR_119444.1 & From Gene bank \\
Uncultured ectomycorrhizal fungus & KU861489.1 & From Gene bank \\
Rhizopogon salebrosus & KC170120.1 & From Gene bank \\
Rhizopogon fallax & KC152199.1 & From Gene bank \\
Rhizopogon atroviolaceus & AF377131.1 & From Gene bank \\
Rhizopogon semireticulatus & AF058307.1 & From Gene bank \\
Uncultured Rhizopogon & KP403084.1 & From Gene bank \\
\hline & & \\
\hline & &
\end{tabular}

\section{RESULTS}

\section{Taxonomic description}

Rhizopogon cashmerianus M.D. Talie \& A.H. Wani sp. nov.

Fig. 3 (a-h)

\section{Mycobank number: MB834836}

Diagonosis: Basidiocarp globose to subglobose or irregular sometimes, smooth, black to brown in colour, on reaction with $\mathrm{KOH}$ changes to black immediately. Basidiospores subglobose or round, measuring about 10-12 $\mu \mathrm{m}$, dark brown, thick walled, ornamented with raised reticulation, dextrinoid, cystidia, basidioles and clamp connections present.

Etymology: In Latin cashmerianus, refers to Kashmir from where the specimen was collected for the first time.
Holotype: INDIA. Jammu and Kashmir UT: Kupwara Forest, found to be associated with Pinus wallichiana A.B. Jakes. $34.4319^{\circ} \mathrm{N}, 74.1240^{\circ} \mathrm{E}, 1600-1657 \mathrm{~m}$, May 17, 2018, M.D. Talie \& A.H. Wani, KASH-2922-Holotype (GenBank RKMK 692540, Mycological Section of KASH Herbarium, Centre of Plant Taxonomy, Division of Botany, University of Kashmir Hazratbal, Srinagar -190006. Jammu and Kashmir, India.

\section{Taxonomy}

Basidiomata (sporocarp) of Rhizopogon cashmerianus is hypogeous to subepigeous, globose to subglobose or sometimes irregular with a basal point of attachment. It reaches up to 5.8-7.7 $\times 4.6-6.3 \mathrm{~cm}$ in size. Peridium dry, smooth, black to brown in colour. On reaction with $\mathrm{KOH}$ it changes to black immediately. Gleba loculate, white in colour when young and becomes brown at maturity, columella absent (Fig.3 a-b). Rhizomorphs originate from the base of sporocarp singly, thick at the base and tapering towards lower end, dark brown to black in colour. Odor pleasant, tasteless, edibility unknown. Periderm thin, measuring about 200-450 $\mu \mathrm{m}$, composed of thick walled, double layered, hyaline, hollow, septate, and loosely interwoven hyphae about 1.5-2.5 $\mu \mathrm{m}$ in diameter. Trama composed of hyaline, loosely interwoven, irregular, septate hyphae measuring about 3.5$5.2 \mu \mathrm{m}$ in diameter. Basidia 13.6-16.6 × 9.2-12.3 $\mu \mathrm{m}, 02-04$ spored, sterigamtal attachment evident.

Basidiole hyaline, clavate, measuring about 20.2-23.4 × 9.5$11.3 \mu \mathrm{m}$ (Figs.3 g-h). Basidiospores subglobose or round in shape measuring about $09-12 \mu \mathrm{m}$, dark brown, hyaline in $\mathrm{KOH}$, dextronoid, thick walled, ornamented with raised reticulation (Fig.3 c). Cystidia clavate, with a long stalk, measuring about $70-75 \mu \mathrm{m}$ in length, $2.5-4.2 \mu \mathrm{m}$ in breadth at the base and 14.3-16.4 $\mu \mathrm{m}$ at the apex (Fig.3 g). Clamp connections present.

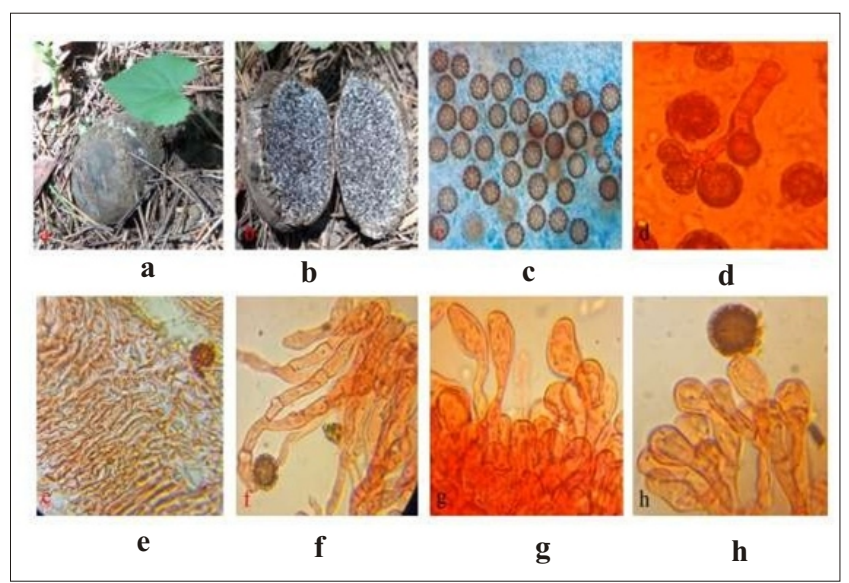

Fig. 3 (a-h): Rhizopogon cashmerianus: (a) Globose fruiting body; (b) Cross section of basidiocarp; (c) Basidiospores in Melzer's reagent; (d) 4-spored basidia; (e) Section of peridium in Congo red; (f) Hyphae of trama in Congored; (g) Cystidia and basidioles in Congo red; (h) Basidia with sterigma and single basidiospore in Congo red. 
Habit and Habitat: Hypogeous to subepigeous showing putative ectomycorrhizal association with Pinus wallichiana at an elev. of 1600-1657 m, fruiting from April-June. So far only known in Kashmir Himalaya, India.

Specimens examined: INDIA. Jammu and Kashmir UT: Kupwara and Handwara Forests, found in association with Pinus wallichiana A.B. Jacks. $34.4319^{\circ} \mathrm{N}, 27 \quad 74.1240^{\circ} \mathrm{E}$, 1600-1657 m, 17 May 2018, M.D. Talie \& A.H. Wani, KASH-2922, KASH-2923,KASH-2924.

Phylogenetic analysis: To elucidate the phylogenetic relationship of ITS nucleotide sequence of Rhizopogon cashmerianus with related nucleotide sequences, a phylogenetic analysis was performed by maximum likelihood method using the MUSCLE program and

MEGA-7 software. The phylogenetic relationship of ITS sequences was determined in order to get insights of evolutionary distance, a phylogenetic analysis of nucleotide sequences with related ITS sequences from BLAST analysis was performed. Pairwise alignment of deduced primary ITS sequences showed that these are highly similar, with great identity at nucleotide level. From the phylogenetic tree analysis, it is clear that $R$. cashmerianus aligned in close proximity with Rhizopogon himalayensis (MH878765.1) in comparison to other Rhizopogon species (Fig.4).

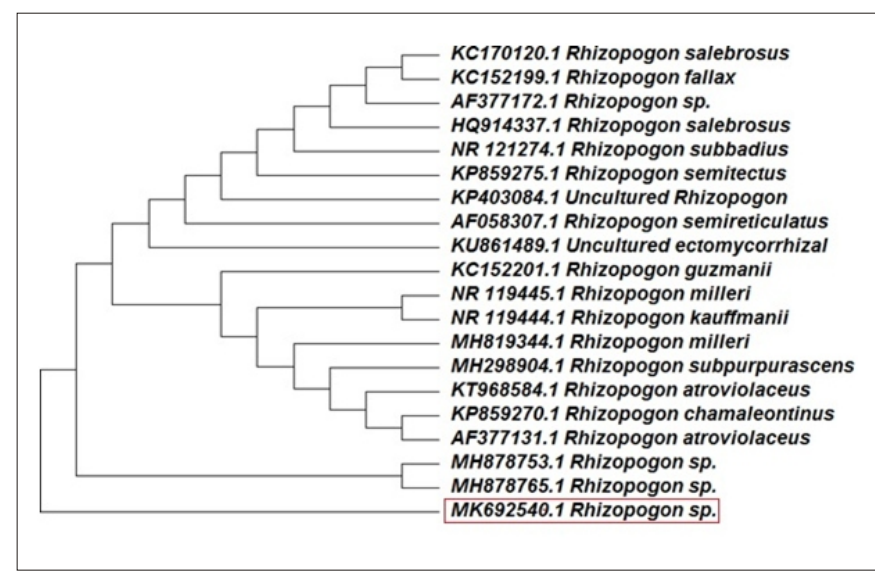

Fig. 4. Phylogenetic analysis of Rhizopogon cashmerianus

Fig. 4. Phylogenetic analysis of Rhizopogon cashmerianus: The analysis involved alignment of 20 nucleotide sequences which were chosen by BLAST search of Rhizopogon from NCBI data-base. The tree with the highest log likelihood (638.6384) is shown. Initial tree for the heuristic search were obtained automatically by applying Neighbor-Join and BioNJ algorithms to a matrix of pairwise distances estimated using the Maximum Composite Likelihood (MCL) approach, and then selecting the topology with superior log likelihood value. All positions containing gaps and missing data were eliminated. There was a total of 341 positions in the final dataset.

\section{DISCUSSION}

From the morphological, anatomical and molecular characters, the examined collections of Rhizopogon appear to represent a new species which has been named as $R$. cashmerianus sp. nov. The species was taxonomically characterized and its phylogenetic relationship with gene sequences information available in databases was analyzed using bioinformatics tools. $R$. cashmerianus possesses altogether different basidiospore and rhizomorph morphology in comparison to all other known Rhizopogon species. The presently named species was found associated with the Pinus wallichiana trees unlike Rhizopogon himalayensis which shows association with Cedrus deodara (Mujic et al., 2019). All previously described species of Rhizopogon possess smooth ellipsoid or smooth ellipsoidtruncate basidiospores bearing two prongs along the edge of the basal truncation (Smith, 1964; Smith and Zeller, 1966; Martin, 1996; Visnovsky et al., 2010; Walbert et al., 2010) except $R$. himalayensis which possess globose to subglobose non dextrinoid basidiospores with irregular reticulations (Mujic et al., 2019). However, the basidiospores of $R$. cashmerianus are larger, thick walled, unique because they are globose to subglobose, dextrinoid, dark brown and ornamented having fused ridges forming a complete reticulum as compared to $R$. himalayensis (Mujic et al., 2019). Cystidia and clamp connections are also present in $R$. cashmerianus as compared to $R$. himalayensis and some other species of Rhizopogon in which they are absent (Mujic et al., 2019) (Table-2). Furthermore, taxonomic identification is also supported by molecular studies. The rDNA sequence of this species forms a distinct clade from rest of the species of Rhizopogon.

Table 2: Comparison between $R$. cashmerianus with its closely allied species R. himalayensis.

\begin{tabular}{ll}
\hline $\boldsymbol{R}$. himalayensis & R. cashmerianus \\
\hline 1. Associated with Cedrus deodara & Associated with Pinus wallichiana \\
2. Basidiomata $0.5-4.0 \mathrm{~cm}$ in diameter & Basidiomata $3.0-7.7 \mathrm{~cm}$ in diameter \\
3. Taste of boiled potato & Tasteless \\
4. No distinctive odor & Pleasant odor \\
5. Periderm 140-300 $\mu \mathrm{m}$ thick & Periderm 200-450 $\mu \mathrm{m}$ thick \\
6. Peridermal hyphae thin walled & Peridermal hyphae thick walled \\
7. Tramal hyphae gelatinized & Tramal hyphae not gelatinized (dry) \\
8. Clamp connections absent & Clamp connections present \\
9. Basidia 40-45 x 5-8 $\mu \mathrm{m}$ and 1 & Basidia 13-16 x 9-12 $\mu \mathrm{m}$ and 2-4 \\
$\quad$ or 2 spored spored & \\
10. Basidiospores non-dextrinoid & Basidiospores dextrinoid \\
11. Cystidia absent & Cystidia present \\
\hline
\end{tabular}

\section{CONCLUSION}

A new species of truffle like mushroom $R$. cashmerianus has been described on the basis of morpho-anatomical and molecular sequence studies. The identified species of mushroom was found forming putative association with Pinus wallichiana.

\section{ACKNOWLEDGEMENT}

The authors are thankful to Head, P.G. Department of Botany, University of Kashmir, for providing necessary facilities, KASH Herbarium and Mycobank for specimen deposition and valuable suggestions. The first author is thankful to CSIR, NEW DELHI, India for providing financial assistance. 


\section{REFERENCES}

Arora, D. 1986. Mushrooms Demystified. A comprehensive guide to the fleshy fungi. Berkeley, California: Ten Speed Press. pp.959.

Atri, N.S., Kaur, A. and Kaur, H.2005.Wild mushroomscollection and identification. In: Frontier in mushroom biotechnology. (Eds.: Rai, R.D., Upadhyay, R.C. and Sharma, S.R.), NRCM Chambaghat, Solan: 9-26.

Beig, M.A., Dar, G.H., Khan, N.A. and Ganai, N. A. 2011. Seasonal production of epigeal Fungal sporocarps in mixed and pure Fir (Abies pindrow) stands in Kashmir forests. Journal of Agricultural Technology 7:1375-1387.

Bruns, T.D., Fogel, R.,White, T.J. and Palmer, J.D. 1989. Accelerated evolution of a false-truffle from a mushroom ancestor. Nature 339:140-147.

Castellano, M.A., Miller, S.L., Singh, L. and Lakhanpal,T.N.2012. Trappeindia himalayensis gen. et sp. nov., a sequestrate fungus with potential affinity to Strobilomyces (Basidiomycotina, Boletales). Kavaka 40: 3-5.

Castellano, M.A., Trappe, J.M., Maser, Z. and Maser, C. 1989. Key to spores of the genera of hypogeous fungi of north temperate forests. Eureka, California: Mad River Press. Pp.3184.

Dar,G.H., Beig, M.A. and Ganai, N.A. 2009. Hithertounrecorded macrofungi from India. Applied Biological Research 11: 59-62.

Dar, G.H., Ganai, N.A., Beigh, M.A., Ahanger, F.A. and Sofi, T.A. 2010. Biodiversity of macro-fungi from conifer dominated forests of Kashmir, India. Journal of Mycology and Plant Pathology 40:169-171.

Grubisha, L.C., Trappe, J.M., Molina, R. and Spatafora, J.W. 2002. Biology of the ectomycorrhizal genus Rhizopogon. VI. Re-examination of infrageneric relationships inferred from phylogenetic analyses of ITS sequences. Mycologia 94:607-619.

Halling, R.E. 1996. Recommendations for collecting mushrooms for scientific study. Selected Guidelines for Ethnobotanical Research: A field manual of the New York Botanical Garden Press Bronx. pp. 135141.

Jukes, T.H. and Cantor, C.R.1969. Evolution of protein molecules. In: Mammalian Protein Metabolism. (Ed.: Munro H.N.), Academic Press. New York 21132.

Kirk, P.M., Cannon, P.F., Minter, D.W. and Stalpers, J.A. 2008. Dictionary of the Fungi Wallingford. UK: CABI.

Kumar, S., Stecher, G. and Tamura, K. 2016. MEGA7: molecular evolutionary genetics Analysis version7.0 for bigger datasets. Molecular biology and evolution 33:1870-1874.

Malik, A.R., Wani, A.H., Bhat, M.Y.and Parveen, S. 2017. Ethnomycological knowledge of Some wild mushrooms of northern districts of Jammu and Kashmir,India. Asian Journal of Pharmaceutical and Clinical Research 10: 399-405

Malik, A. R., Wani, A. H., Ganaie, B. A. Bhat, Z. A. and Parveen, S. 2018. Hitherto unreported species of Ascomycetous Macrofungi of Kashmir Himalaya. IJASR, 7(4): 2145-2155.

Martin, M.P. 1996.The genus Rhizopogon in Europe. Societat Catalanade Micologia 5:1-171.

Molina, R., Trappe, J.M., Grubisha, L.C. and Spatafora, J.W. 1999. Rhizopogon. In: Ectomycorrhizal fungi key genera in profile. (Eds.: Cairney, J.W.C. and Chambers, S.M.), Springer, Berlin. Heidelberg: 129-161.

Mujic, A.B., Zheng, N., Kim, K., Spatafora, J.W., Castellano, M.A. and Smith, M.E. 2019. The Cedrus-associated truffle Trappeindia himalayensis is a morphologically unique and phylogenetically divergent species of Rhizopogon. Mycologia 111: 225-234.

Pala, S.A., Wani, A.H. and Bhat, M.Y. 2011. Six hithertounreported Basidiomycetic macrofungi from Kashmir Himalayas. Nusantara Bioscience 3:9297.

Pala, S.A., Wani, A.H., Boda, R.H. and Mir, R.A. 2012.Three hitherto-unreported macrofungi from Kashmir Himalaya. Pakistan Journal of Botany 44(6): 21112115

Simard, S.W. 2009. The foundational role of mycorrhizal networks in self-organization of interior Douglas-fir forests. Forest Ecology and Management 258: 95 107.

Smith, A.H. and Zeller, S.M.1966. A preliminary account of the North American species of Rhizopogon. Memoirs of the New York Botanical Garden 14: 1178.

Smith, A.H. 1964. Rhizopogon a curious genus of false Truffles. The Michigan Botanist 3:13-19.

Trappe, J., Molina, R., Luoma, D., Cazares, E., Pilz, D., Smith, J., Castellano, M., Miller, S. and Trappe, M. 2009. Diversity, ecology, and conservation of truffle fungi in forests of the Pacific Northwest. General Technical Report PNW-GTR-772. Portland, Oregon: USDA Forest Service, Pacific Northwest Research Station. pp.194.

Twieg, B.D., Durall, D.M. and Simard, S.W. 2007.Ectomycorrhizal fungal succession in mixed temperate forests. New Phytologist 176: 437-447.

Visnovsky, S.B., Guerin-Laguette, A., Wang, Y. and Pitman, A.R.2010.Traceability of marketable Japanese shoro in New Zealand: using multiplex PCR to 
exploit phylogeographic variation among taxa in the Rhizopogon subgenus Roseoli. Applied Environmental Microbiology 76: 294-302.

Walbert, K., Ramsfield, T.D.,Ridgway, H.J.and Jones, E.E.2010. Ectomycorrhizal species Associated with Pinus radiate in New Zealand including novel associations determined by molecular analysis. Mycorrhiza 20: 209-215.

Wani, A.H., Boda, R.H. and Pala, S.A. 2015. Two new records of mushrooms from Kashmir Valley. Mycopathologia 13(1): 21-23.
Wani, A.H., Pala, S.A., Boda, R.H. and Mir, R.A. 2010. Morels in southern Kashmir Himalaya. Journal of Mycology and Plant Pathology 40: 540-546.

White, T.J., Bruns, T., Lee, S.J.W.T. and Taylor, J.1990.Amplification and direct sequencing of fungal ribosomal RNA genes for phylogenetics. PCR protocols: a guide to methods and applications 18: 315-322. 